\title{
Melatonin deficiency or excess and various-genesis stressful situations influence on liver functioning
}

\author{
O.I. Antonova, A.V. Pasenko \\ Kremenchuk Mykhailo Ostrohradskyi National University; e-mail: antonovaei@ukr.net
}

\begin{abstract}
The paper deals with the research of the functional, pro- and antioxidant condition of the liver under the impact of stressful situation of various geneses. The markers of the oxidizing stress included: diethen conjugates, xanthine oxidase activity, cyclic adenosine monophosphate. The state of the liver pro- and antioxidant system was assessed by the increase of the peroxidation secondary oxoproducts mainly malondialdehyde (MDA) under the conditions of spontaneous and induced (ascorbate-depending and enzymatic) peroxidation and also by the activity of superoxide dismutase and catalase, content of restored and oxidized forms of glutathione in the liver. General proteolytic activity in the liver tissue was determined. Total bilirubin and its fractions were determined according to the standard method of Jendrashek with the use of diazoreagent. It was found out that the action of aggravators causes increase of non-enzymatic free-radical peroxide oxidation of biopolymers. It turned out that at the lack of melatonin the content of diene conjugate increases by $30 \%$ but there was a tendency to decrease of the content of MDA by 30\%. Thus, it is observed that only the concentration of primary peroxidation products increase, which may certify the intensification of peroxidation in the liver. At the impact of increased doses of melatonin the peroxidation processes in the liver reduced, which is proved by half as big content of MDA, i.e. melatonin acted as an antioxidant. The research of the liver functional state under the conditions of the oxidizing stress made it possible to identify in the liver twice as high content of diethen conjugates and MDA in comparison with the control value, which characterize the peroxidation processes.Thus, a conclusion can be made that stressful situations cause intensification of peroxidation in the liver, which may contribute to various diseases.
\end{abstract}

Key words: stress; liver; pro- and antioxidant balance.

\section{INTRODUCTION}

Nowadays human life is connected with environment pollution and action of harmful chemical and physical agents causing wide spread of stresses of chemical genesis. That is why the study of the stresses of chemical genesis and their influence on organism functioning is one of the topical problems of the physiology of man and animals. Oxidative stress is caused by active forms of oxygen; it results in the inability of the cells to overcome the increase of release of active form of oxygen and damage of the cells. Oxidative stress is the cause of many serious human diseases [1]. Melatonin protects the organism cells against oxidation that contributes to occurrence of serious illnesses including cancer, heart diseases, diabetes, asthma. It is for this (C) O.I. Antonova, A.V. Pasenko reason that melatonin is important as a strong antioxidant, absorber of active forms of oxygen [2]. The research of the melatonin deficiency and excess influence on the state of the liver at its normal functioning and under the conditions of the oxidizing stress is limited by single scientific studies. Recently, some papers contained the analysis of melatonin influence on regulation of the antioxidant homeostasis and the system of the body detoxification by the melatonin hormone and the role of the melatonin-dependent receptors and the realization of this function in the oxidative status [3]; the content of citrate and the activity of aconitate hydratase in rat's liver at toxic hepatitis [4]; the morphological structure of white rats' liver under the condition of the stress on the background of the hypo- and hyper-functions of the epiphysis [5]; the clinical 
efficiency of melatonin and its impact on the free radical homeostasis at toxic lesions of the liver [6]. However, the physiological substantiation of the used melatonin doses remains insufficient and the data of its impact on the liver functional state are practically absent. Besides, there are situations when the person's professional activity takes place under the condition of constant lighting and it is possible to consider that in these cases not enough melatonin is synthesized in the body [7]. Taking into account the stressfulness of the contemporary human life the hypo- and hyper-melatonin states are often formed on the background of the stress, including the chemical one connected with a great number of chemical substances found in the body. Thus, the research of melatonin excess or deficiency, especially on the background of the stress, impact on the liver functional state is of particular interest.

Therefore, the topicality of the problem and its insufficient study require research in this field.

\section{METHODS}

To research the influence on the liver of stress, hypo- and hyper-melatonin state, intoxication by sodium peroxiborate four series of experimental research on animals - Wistar line rats (46 rats), of the average mass of $240 \mathrm{~g}$ (from $220 \mathrm{~g}$ to 260 g) were carried out. All the experimental procedures were performed according to the norms of bioethics. The animals were kept on the standard vivarium ration. Stress was reproduced by the classical H. Selye's method - the animals were fixed on back, the first experimental group was kept in this position for one hour and the second group - for five hours. Two hours after finishing the stress impact euthanasia by decapitation was performed. To correct the effects of five-hour stress, one hour before the experiment, the rats were given per os 1/10 of a capsule of food additive ACTIVIN OPS 50 (it is a complex of natural antioxidants and microelements - vitamins E, C, P, B-carotene, selenium and others) or $1 / 10$ of tablet of food additive MELATONIN (one tablet contains $2 \mathrm{mg}$ of melatonin and a complex of antioxidants). Hypo-melatonin state was simulated by continuous lighting with electric bulbs during 10 days and nights $(1000-1500$ lux 24 hours a day). Hyper-melatonin state was simulated by introduction of melatonin during 10 days and nights (the rats received melatonin in the dose of $0.3 \mathrm{mg} / \mathrm{kg}$ of the body mass in the form of $0.01 \%$ water solution, the individual dose was $0.54-0.59 \mathrm{ml})$. The following stage of the work consisted in the research of the oxidative stress of chemical genesis. Simulating the conditions of the oxidative stress a dose of $0.05 \mathrm{LD}_{100}(60$ $\mathrm{mg} / \mathrm{kg}$ of the body mass in 24 hours) of sodium peroxiborate was used in the experiment during 10 days and nights.

Determination of the concentration of diene conjugates, activity of xanthine oxidase and cyclic adenosine monophosphate (c-AMP) were used as markers of oxidative stress. The state of the liver pro-antioxidant system was assessed by the increase of the peroxidation (PO) secondary oxoproducts mainly malondialdehyde (MDA) under the conditions of spontaneous and induced (ascorbate-depending and enzymatic) peroxidation and also by the activity of superoxide dismutase (SOD) and catalase according [8,9]. The content of deoxidized (GSH) and oxidized (GSSG) glutathione forms in the liver, the general proteolytic activity in the liver tissues, total bilirubin and its fractions by Jendrassik method have been determined with the use of a diazoreagent. The samples of the liver tissue were selected at once after the slaughter of the animals and the tissue antigens were prepared. All the research was carried out according to generally accepted methods [10]. The digital data obtained during the research were subjected to a statistical analysis with the use of the standard methods of variation statistics. The standard statistic indices were determined: arithmetic mean (M), arithmetic mean error $(\mathrm{m})$, probability of difference between the mean values $(\mathrm{P})$, standard distortion (t) by the Student's criterion. Differences at $\mathrm{P} \leq 0.05$ were considered reliable. 


\section{RESULTS AND THEIR DISCUSSION}

At an acute stress of hopelessness (swimming) the activity of xanthine oxidase in the rats' liver is $1578 \pm 858 \mathrm{mcat} / \mathrm{kg}(\mathrm{n}=7)$ with the norm of $1083 \pm 321 \mathrm{mcat} / \mathrm{kg}(\mathrm{n}=8)$, i.e. practically it did not change. At an acute emotionally-painful stress of expectation (stochastic electro-irritations) the concentration of cyclic adenosine monophosphate (cAMP) increased by eight times in the rats' liver (Table 1). At the rats' acute immobilization stress in the dynamic of observations the chondriosome oxidation is the main source of superoxide in the liver, to a smaller degree it was a phagocytic respiratory explosion inhibited by cateholamines.

Extract of the liver of the stressed rats, being added to intact plasma, contributed to reduction of the recalcification time almost by two times -the thrombin time, making the time of euglobulins fibrinolysis almost twice as long (Table 2).

Table 1. The state of liver pro- and antioxidant at an acute emotional-painful stress of expectation (M $\pm \mathbf{m})$

\begin{tabular}{l|c|c|}
\hline \multicolumn{1}{|c|}{ Indices } & Norm & Stress \\
\hline MDA-0, $\mu \mathrm{mol} / \mathrm{l}$ & $17.74 \pm 2.01$ & $21.75 \pm 2.35$ \\
$\mathrm{MDA}-1.5, \mu \mathrm{mol} / \mathrm{l}$ & $20.53 \pm 2.21$ & $25.36 \pm 2.41$ \\
$\mathrm{D}$ & 16 & 17 \\
Catalase, mcat/kg & $4.12 \pm 0.51$ & $3.56 \pm 0.26$ \\
SOD, un.act. & $1.38 \pm 0.15$ & $1.59 \pm 0.13$ \\
$\mathrm{cAMP}, \mathrm{pmol} / \mathrm{g}$ & $0.60 \pm 0.07$ & $4.80 \pm 0.11^{*}$ \\
\hline \hline
\end{tabular}

Note: $* \mathrm{P}<0.01$ in comparison with control

Table 2. Influence of the extracts of the liver of intact and stressed rats on some indices of blood coagulation (M \pm m)

\begin{tabular}{|c|c|c|}
\hline \multirow{2}{*}{ Indices } & \multicolumn{2}{|c|}{ Rats' liver extract } \\
\hline & Intact & Stressed \\
\hline Recalcification time, $\mathrm{s}$ & $93.70 \pm 0.88$ & $84.80 \pm 3.65^{*}$ \\
\hline Thrombin time, s & $33.70 \pm 0.67$ & $16.80 \pm 1.57 * *$ \\
\hline Euglobulins fibrinolysis, min & $112.2+10.2$ & $198.3 \pm 15.9 * *$ \\
\hline
\end{tabular}

Note: $* \mathrm{P}<0.01 ; * * \mathrm{P}<0.001$ in comparison with control

As a result of an acute emotional-painful stress the levels of free-radical peroxidation (FRPO) processes in the rats' liver did not change, the content of cAMP increased by eight times, the activity of liver catalase did not change. The hyperoxidation effect during the stress is described and it characterizes the stage of anxiety that may not be synchronous in the blood and organs having bigger antioxidant potential stimulated by cAMP. Five-hour fixation of rats on backs increases the production of superoxide by the liver phagocytes in the process of chondriosome and microsomal oxidation in the testicles; previous introduction of natural antioxidant complexes in increased doses also intensifies superoxide production (Table 3).
Hypokinesia and hyperkinesia (as variants of rats' stress) influence the ultrastructure of the liver cells [13] and intensify FRPO in the liver [14].

Research of 10-day lack of melatonin revealed disturbance of pro- and antioxidant balance accompanied by intensification of free-radical oxidation, which was manifested by increase of lipid peroxidation of the primary products content - diene conjugates (Table 4) [15].

The content of diene conjugates increased by $30 \%(\mathrm{P}<0.05)$, but there was a tendency to decrease of the content of malondialdehyde by $30 \%(\mathrm{P}<0.1)$. Thus, only the increase of concentration of peroxidation primary products is observed. The activity of SOD, catalase and glutathione peroxidase did not change essentially. General proteolytic activity (GPA) did 
Table 3. Spectrophotometric NBT-test of rats' liver at stress $(\mathrm{M} \pm \mathbf{m})$

\begin{tabular}{|l|ccc|}
\hline \multirow{2}{*}{ Experiments series } & \multicolumn{3}{c|}{ Stimulation } \\
\cline { 2 - 4 } & $\mathrm{NADPN}_{2}$ & $\mathrm{NADN}_{2}$ & Lipopolysaccharide \\
\hline Liver, norm (4) & $7.67 \pm 1.37$ & $7.93 \pm 0.33$ & $1.04 \pm 0.33$ \\
stress 1 hour (3) & $10.87 \pm 2.13$ & $10.80 \pm 0.27 * *$ & $0.89 \pm 0.13$ \\
stress 5 hours (3) & $10.33 \pm 2.00$ & $6.67 \pm 0.20^{* * * * * * * *}$ & $1.72 \pm 0.16^{* * * * *}$ \\
stress 5 hours + complex AO (3) & $11.67 \pm 2.09$ & $12.00 \pm 2.51 * * * * * *$ & $1.36 \pm 0.18$ \\
stress 5 hours + complex with M (3) & $16.17 \pm 2.73^{*}$ & $10.17 \pm 1.07 *, * * * * * *$ & $1.31 \pm 0.03 * * * * * *$ \\
\hline
\end{tabular}
Note: $* \mathrm{P}<0.1 ; * * \mathrm{P}<0.001 ; * * * \mathrm{P}<0.05$ in comparison with control; $* * * * \mathrm{P}<0.1 ; * * * * * \mathrm{P}<0.02$ comparison of the stress duration effects; $* * * * * * \mathrm{P}<0.1$; ******* $\mathrm{P}<0.05$ comparison of correction effect with the data of 5 -hour stress $[11 ; 12]$.

not change essentially either. In blood serum the activity of alanine aminotransferase did not change essentially. The concentration of the total bilirubin did not change and met the norm. Thus, at 10-day lack of melatonin the increase of the content of diene conjugates was detected, which may certify the intensification of peroxidation in the liver.
Research of 10-day melatonin excess influence on the liver functional state revealed the following (Table 5): there were no essential changes in diene conjugates concentration in the liver but MDA content was half as high $(\mathrm{P}<0.01)$, i.e. melatonin proved to be an antioxidant [16]. The activity of SOD, catalase and glutathione peroxidase did not change essentially. GPA did

Table 4. Biochemical parameters at the lack of melatonin $(\mathrm{M} \pm \mathrm{m})$

\begin{tabular}{l|c|c|c|}
\hline \multicolumn{1}{c|}{ Indices } & \multirow{2}{*}{ Research object } & \multicolumn{2}{|c|}{ Groups } \\
\cline { 3 - 4 } & & I (norm) & II \\
\hline Content of diene conjugates, $\mu \mathrm{mol} / \mathrm{kg}$ & Liver homogenate & $9.44 \pm 0.15$ & $14.04 \pm 2.26^{* *}$ \\
Content of MDA, $\mu \mathrm{mol} / \mathrm{kg}$ & $45.89 \pm 5.55$ & $31.89 \pm 5.37^{*}$ \\
$\mathrm{SOD}$, un.act. & & $0.534 \pm 0.133$ & $0.361 \pm 0.10$ \\
Catalase, $\mathrm{mcat} / \mathrm{kg}$ & $5.25 \pm 0.17$ & $5.20 \pm 0.77$ \\
Activity of glutathione peroxidase mcat $/ \mathrm{kg}$ & Liver homogenate & $6.03 \pm 0.35$ & $5.43 \pm 0.46$ \\
General proteolytic activity, ncat/kg mcat/1 & Liver homogenate & $16.57 \pm 4.03$ & $13.84 \pm 4.19$ \\
ALT, $\mu$ cat $/ \mathrm{l}$ & Blood serum & $0.46 \pm 0.05$ & $0.41 \pm 0.008$ \\
Total bilirubin, $\mu \mathrm{mol} / \mathrm{l}$ & Blood serum & $6.24 \pm 0.69$ & $4.69 \pm 0.67$ \\
\hline
\end{tabular}

Note: $* \mathrm{P}<0.1 ; * * \mathrm{P}<0.05$ in comparison with the values in group I.

Table 5. Biochemical parameters at hyperfunction $(\mathrm{M} \pm \mathbf{m})$

\begin{tabular}{|c|c|c|c|}
\hline \multirow{2}{*}{ Indices } & \multirow{2}{*}{ Research object } & \multicolumn{2}{|c|}{ Groups } \\
\hline & & I (norm) & II \\
\hline Content of diene conjugates, $\mu \mathrm{mol} / \mathrm{kg}$ & Liver homogenate & $9.44 \pm 0.15$ & $10.17 \pm 0.72$ \\
\hline Content of MDA, $\mu \mathrm{mol} / \mathrm{kg}$ & & $45.89 \pm 5.55$ & $23.46 \pm 3.39^{*}$ \\
\hline SOD, un.act. & & $0.534 \pm 0.133$ & $0.387 \pm 0.079$ \\
\hline Catalase, mcat $/ \mathrm{kg}$ & & $5.25 \pm 0.17$ & $5.1 \pm 0.20$ \\
\hline Activity of glutathione peroxidase mcat $/ \mathrm{kg}$ & Liver homogenate & $6.03 \pm 0.35$ & $5.25 \pm 0.42$ \\
\hline General proteolytic activity, ncat/kg; mcat/1 & Liver homogenate & $16.57 \pm 4.03$ & $11.34 \pm 2.42$ \\
\hline ALT, $\mu \mathrm{cat} / 1$ & Blood serum & $0.46 \pm 0.05$ & $0.34 \pm 0.05$ \\
\hline Total bilirubin, $\mu \mathrm{mol} / 1$ & Blood serum & $6.24 \pm 0.69$ & $4.37 \pm 1.20$ \\
\hline
\end{tabular}

Note: $* \mathrm{P}<0.01$ in comparison with the values in group I. 
Table 6. Biochemical parameters at intoxication $(\mathrm{M} \pm \mathrm{m})$

\begin{tabular}{|c|c|c|c|}
\hline \multirow{2}{*}{ Indices } & \multirow{2}{*}{ Research object } & \multicolumn{2}{|c|}{ Groups } \\
\hline & & I (control) & II (SPOB) \\
\hline Content of diene conjugates, $\mu \mathrm{mol} / \mathrm{kg}$ & Liver homogenate & $9.44 \pm 0.15$ & $17.92 \pm 1.51 * *$ \\
\hline Content of MDA, $\mu \mathrm{mol} / \mathrm{kg}$ & & $45.89 \pm 5.55$ & $92.85 \pm 26.70^{*}$ \\
\hline SOD, un.act. & & $0.534 \pm 0.133$ & $0.205 \pm 0.068 * * *$ \\
\hline Catalase, mcat $/ \mathrm{kg}$ & & $5.25 \pm 0.17$ & $2.70 \pm 0.30 * *$ \\
\hline Activity of glutathione peroxidase mcat $/ \mathrm{kg}$ & Liver homogenate & $6.03 \pm 0.35$ & $3.89 \pm 0.21 * *$ \\
\hline General proteolytic activity, ncat/kg; mcat/l & Liver homogenate & $16.57 \pm 4.03$ & $21.11 \pm 4.91$ \\
\hline Total bilirubin, $\mu \mathrm{mol} / 1$ & Blood serum & $6.24 \pm 0.69$ & $9.58 \pm 1.14 * * *$ \\
\hline
\end{tabular}

Note: $* \mathrm{P}<0.1 ; * * \mathrm{P}<0.001 ; * * * \mathrm{P}<0.05$ in comparison with the value in group I.

not change essentially either. In blood serum the activity of alanine aminotransferase and bilirubin concentration did not change.

Thus, at 10-day impact of increased melatonine doses the peroxidation processes in the liver reduced, which is proved by less content of MDA.

Research of the functional state of the liver under the conditions of oxidative stress made it possible to identify essential differences in the state of the liver pro-antioxidant system. During the 10-day research the increased content of diene conjugates and MDA by almost 2 times (respectively $\mathrm{P}<0.001$ and $\mathrm{P}<0.1)$ were detected in the liver in comparison with the control values (Table $6)$, that characterize the processes of peroxidation.

At that time the antioxidant processes in the liver decreased, which is expressed by reduction of SOD in the liver by 2.6 times $(\mathrm{P}<0.05)$ in comparison with the control value. The activity of catalase in the liver also decreased by almost 2 times $(\mathrm{P}<0.001)$ in comparison with the norm. The activity of glutathione peroxidase reduced by $35 \%(\mathrm{P}<0.001)$. In this case GPA did not change and bilirubin concentration in the blood serum increased by $54 \%(\mathrm{P}<0.05)$. The concentration of total bilirubin increased, which caused certain changes on the part of the liver metabolic function.

\section{CONCLUSIONS}

1. Most performed experiments revealed that the action of aggravators causes intensifica- tion of biopolymer non-enzymatic free-radical peroxidation.

2. Lack and excess of melatonin under the experimental conditions can change the proantioxidant balance of the liver and metabolic function. Lack of melatonin causes the disorder of the pro-antioxidant balance of the liver in the direction of the prooxidant link. Excess of melatonin causes the disorder of the pro- and antioxidant balance of the liver in the direction of the antioxidant link.

3. Intoxication by sodium peroxiborate resulted in the disorder of the pro-antioxidant balance, which manifested in the increase of the content of the primary and secondary peroxidation products - diene conjugates and malondialdehyde, and the inertness of the enzymatic system of antioxidant protection shown in decrease of the activity of superoxide dismutase, catalase and glutathione peroxidase.

The author of this study, O.I. Antonova, A.V. Pasenko, confirm that the research and publication of the results were not associated with any conflicts regarding commercial or financial relations, relations with organizations and/or individuals who may have been related to the study, and interrelations of co-authors of the article. 


\section{О.I. Антонова, А.В. Пасенко}

\section{ВПЛИВ НЕСТАЧІ Й НАДЛИШКУ МЕЛАТОНІНУ ТА СТРЕСОВИХ СИТУАЦІЙ РІЗНОГО ГЕНЕЗУ НА ФУНКЦІОНУВАННЯ ПЕЧІНКИ}

Вивчали функціональний, про- та антиоксидантний стан печінки при дії стресових ситуацій різного генезу. Маркерами окисного стресу були: дієнови кон'югати, активність ксантиноксидази, циклічний аденозинмонофосфат. Стан про- та антиоксидантної системи печінки оцінювали за приростом вторинних оксопродуктів пероксидації, переважно малонового діальдегіду (МДА) в умовах спонтанного та індукованого (аскорбатзалежного і ферментативного) перекисного окиснення, а також активністю супероксиддисмутази та каталази, вмістом у печінці відновних та окиснених форм глутатіону. Визначали загальну протеолітичну активність у тканинах печінки. Загальний білірубін та його фракції досліджували за методикою Іендрашика з використанням діазореактиву. Виявилось, що дія подразників викликала посилення неферментативного вільнорадикального перекисного окиснення біополімерів. При нестачі мелатоніну вірогідно збільшувався вміст дієнових кон'югатів на $30 \%$, але спостерігалася тенденція до зниження вмісту малонового діальдегіду на $30 \%$. Таким чином, збільшення концентрації тільки первинних продуктів пероксидації може свідчити про посилення пероксидації у печінці. При впливі підвищених доз мелатоніну пригнічалися процеси пероксидації, про що говорило зменшення вмісту МДА у 2 рази, тобто мелатонін проявив себе як антиоксидант. Дослідження функціонального стану печінки в умовах окисного стресу дало змогу встановити у печінці підвищення вмісту дієнових кон'югатів та МДА (які характеризують процеси пероксидації) у 2 рази порівняно з контролем. Отже, стресові ситуації призводять до посилення пероксидації в печінці, а це може сприяти різним захворюванням.

Ключові слова: стрес; печінка; про- та антиоксидантний баланс.

\section{Е.И. Антонова, А.В. Пасенко}

\section{ВЛИЯНИЕ НЕДОСТАТКА, ИЗБЫТКА МЕЛАТОНИНА И СТРЕССОВЫХ СИТУА- ЦИЙ РАЗЛИЧНОГО ГЕНЕЗА НА ФУНКЦИО- НИРОВАНИЕ ПЕЧЕНИ}

Изучали функциональное, про- и антиоксидантное состояние печени под воздействием стрессовых ситуаций различного происхождения. В качестве маркеров окислительного стресса использовали определение концентрации диеновых конъюгатов, активность ксантиноксидазы, циклического аденозинмонофосфата. Состояние про- и антиоксидантной системы печени оценивали по приросту вторичных оксипродуктов пероксидации, в основном малонового диальдегида (МДА) в условиях спонтанного и индуцированного (аскорбатзависимого и ферментативного) перекисного окисления, а также активностю супероксиддисмутазы и каталазы, содержанием в печени восстановленных и окисленных форм глутатиона. Определялась общая протеолитическая активность в тканях печени. Общий билирубин и его фракции определялись по методике Иендрашика с использованием диазореактива. Было установлено, что действие раздражителей вызывало усиление неферментативного свободнорадикального перекисного окисления биополимеров. При недостатке мелатонина вероятно увеличилось содержание диеновых конъюгатов на $30 \%$, но имела место тенденция к снижению содержания малонового диальдегида на $30 \%$. Таким образом, наблюдалось увеличение концентрации только первичных продуктов пероксидации, что может свидетельствовать об усилении пероксидации в печени. Под влиянием повышенных доз мелатонина снижаются процессы пероксидации, что доказывалось уменьшением содержания МДА в два раза, то-есть мелатонин проявил себя как антиоксидант. Исследования функционального состояния печени в условиях окислительного стресса позволили установить в печени повышение содержания диеновых конъюгатов и МДА (которые характеризуют процессы пероксидации) в 2 раза по сравнению с контролем. Значит, стрессовые ситуации приводять к усилению пероксидации в печени, а это может способствовать разным заболеваниям.

Ключевые слова: стресс; печень; про- и антиоксидантный баланс.

\section{REFERENCES}

1. Baraboi VA, Reznikov AG. The physiology, biochemistry and psychology of stress. Kyiv, Interservis. 2013; 314. [Ukrainian].

2. Bellommo G. Mechanisms of oxidative cell injury. Actaphysiol. scand. Suppl. 1992; 146 (608): 28.

3. Belenichev IF, Gubskii YuI, Levitskii EL, Kovalenko SI. The regulation of the antioxidant homeostasis and the system of the body detoxication by melatonin hormone. The role of the melatonin-dependent receptors in the realization of this function. Modern probl toxicol [electronic resource]. 2003; 2. http://www.medved.kiev.ua/arhiv_mg/ st 2003/03 2 2 $2 / \mathrm{htm}$.

4. Pashkov AN. Melatonin influence on the oxidative status, the content of citrate and the activity of aconitate hydratase in rats' liver at toxic hepatitis. Probl endocrinol. 2005; 48(6): 41-43.

5. Rudyi-Trypolskyi VO. The morphological structure of white rats' liver under stressful condition on the background of the hypo- and hyper-function of the epiphysis. Morph conf. Dnipropetrovsk. 2006; 86. [Ukrainian].

6. Popov SS. The clinical efficiency of melatonin and its impact on the free radical homeostatis at the toxic lesion of the liver. Med Sc Cand thesis. Voronezh. 2008; 25. [Russian]. 7. Petrishchev NN, Kvetnoi IM, Panchenko AV, Anisimov VN. 
The length of the day light phase as a factor modulating the colon carcinogenesis in the experiment. Conf 50 years of melatonine: research results and prospects. St. Petersburg. 2008; 30-2. [Russian].

8. Koroliuk MA, Ivanova LI, Maiorova IG, Tokarev VE. A method for determination of catalase activity. Laboratory business. 1988; 1:16-19.

9. Syrota TV. A new approach to the research of adrenaline autooxidation process and its use for measuring the activity of superoxide dismutase. Probl med chem. 1999; 45(3): 263-72.

10. Kaidashev IP. Methods of clinical and experimental research in medicine. Poltava. Polymet. 2003; 319. [Ukrainian].

11. Tsebrzhynskyi OI, Neporada KS, Denysenko SV. Sources of superoxide generation at an acute stress. Topical probl modern med. 2002; 2; 2(4): 42-4. [Ukrainian].
12. Tsebrzhynskyi OI, Kostenko AH, Kostenko VA. Stress features under the conditions of intoxication and inflammation. Physiol jour. 1998; 44(4): 89. [Ukrainian].

13. Shkurupii VA. Ultrastructure of the liver cells in stress. Novosibirsk. Nauka. 1989; 144. [Russian].

14. Brechko VB, Yeromina OL, Tsebrzhynskyi OI. Influence of different types motion modes on the antioxidant status in the experiment depending on the season and the type of higher nervous activity. Experimental and clinical physiology and biochemistry. 1999; 2:7-10.

15. Antonova OI. Influence on the liver of light and partial deprivation of sleep. J Med biol probl. 2006; 1:18-22. [Ukrainian].

16. Antonova OI, Tsebrzhynskyi OI. Chronic hyper-melatonin condition influence on the state of rats' liver. J Luhansk Taras Shevchenko National Pedagogic University. 2006; 13(108): 6-10. [Ukrainian]. 